\title{
Investigating critical success factors in tile industry
}

\author{
Davood Salmani ${ }^{a^{*}}$, Gholam Reza Taleghani ${ }^{\mathrm{a}}$, Maryam Mollaali ${ }^{\mathrm{b}}$ and Arezoo Salmani ${ }^{\mathrm{c}}$
}

${ }^{a}$ Associate Professor, Department of Management and Accounting, University of Tehran, Tehran, Iran

${ }^{b} M B A$, Payamenoor University

${ }^{c}$ EMBA, Payamenoor University

CHRON I C LE

Article history:

Received October 28, 2013

Received in revised format

25 November 2013

Accepted 29 January 2014

Available online

February 42014

Keywords:

Organizational capabilities

Critical success factors

Marketing planning

Low cost production

\begin{abstract}
A B S T R A C T
This paper presents an empirical investigation to determine critical success factors influencing the success of tile industry in Iran. The study designs a questionnaire in Likert scale, distributes it among some experts in tile industry. Using Pearson correlation test, the study has detected that there was a positive and meaningful relationship between marketing planning and the success of tile industry $(r=0.312$ Sig. $=0.001)$. However, there is not any meaningful relationship between low cost production and success of tile industry $(r=0.13 \mathrm{Sig} .=0.12)$ and, there is a positive and meaningful relationship between organizational capabilities and success of tile industry $(\mathrm{r}=0.635 \mathrm{Sig} .=0.000)$. Finally, our investigation states that technology and distributing systems also influence on the success of tile industry, positively. The study has also used five regression analyses where the success of tile industry was the dependent variable and marketing planning, low cost production and organizational capabilities are independent variables and the results have confirmed some positive and meaningful relationship between the successes of tile industry with all independent variables.
\end{abstract}

(C) 2014 Growing Science Ltd. All rights reserved.

\section{Introduction}

One of the most important issues on the success of economy is to determine critical success factors very carefully and there are many studies associated with the relationships of various factors such as organizational capabilities, marketing planning, etc. (Chen, 2012). Lu et al. (2006), for instance, performed an investigation on a case study of an inter-organizational information system (IOS) of Cisco and Xiao Tong in China by interviewing their senior managers, heads of departments and employees who had been directly influenced in their work. The study tried to find out whether the advantages of the IOS for both firms. The research also disclosed seven critical success factors for the IOS, namely intensive stimulation, shared vision, cross-organizational implementation team, high integration with internal information systems, inter-organizational business process re-engineering, advanced legacy information system and infrastructure and shared industry standard.

\footnotetext{
*Corresponding author.

E-mail addresses: salmani@ut.ac.ir (D. Salmani) 
Sung (2011) performed a survey on the literature of business innovation, determined critical success factors (CSFs) for business innovation, empirically examined the validity of CSFs as well as studied the effect of CSFs on the success of business innovation, and investigated whether CSFs for business innovation are identical or different in normal and crisis economic circumstances. They determined 11 eleven CSFs thorough extensive literature review including motivation and rewards, TF team manpower, strategy, methodology, goals and measurement, organizational structure, change management, role of information technology, implementation, leadership, and communication. Zou et al. (2014) tried to study current perceptions and experiences of RM in PPP projects and more importantly, to detect the CSFs for RM in PPP projects. They reported that industry practitioners currently did not have a general understanding of concepts and applications of RM, given that it was relatively new in PPP.

Borman and Janssen (2013) examined existing research in the area of CSFs and recommended that research actually covered two distinct phenomena. One approach was concentrated on detecting the factors needed for a specific individual to reach their outcomes while the second one was on determining the general success factors for implementing a project of a certain type. Ram et al. (2013) investigated whether some factors labelled as 'critical' success factors for enterprise resource planning (ERP) projects were in practice actually critical for reaching success in implementation and improving output performance. To study this they reported an empirical study that has studied whether four major CSFs were in practice critical for reaching organizational performance improvements, and the role that successful implementation could play in impacting the relationship between CSFs and improvements in organizational performance. They determined that some CSFs were not critical to reach success in ERP implementation but were critical to assist an organizational

achieve performance improvement from an ERP system. In addition, they also determined that achieving successful ERP system implementation could mediate the degree to which a CSF influences output performance improvement.

According to Stankovic et al. (2013), detecting the factors influencing on the success of the software development projects has been the concern for more than 30 years. In recent years, agile methodology of software development has become the dominant one for all types of software development projects. Stankovic et al. (2013) presented the results of empirical investigation for determining critical factors that impact the success of agile software projects conducted among senior developers and project managers from IT companies located in the former Yugoslavia countries within South Eastern Europe (SEE) region.

\section{The proposed study}

This paper presents an empirical investigation on different factors influencing the success of tile industry in Iran. The study designs a questionnaire in Likert scale, distributes it among some experts in tile industry. The study has been applied Pearson correlation ratios as well as three regression analyses to determine the effect of marketing planning, low cost production and organizational capabilities on the success of tile industry in Iran. There are three hypotheses associated with this study as follows,

1. There is a positive and meaningful relationship between marketing planning and the success of tile industry.

2. There is a positive and meaningful relationship between low cost production and the success of tile industry.

3. There is a positive and meaningful relationship between organizational capabilities and the success of tile industry. 
4. There is a positive and meaningful relationship between technology and the success of tile industry.

5. There is a positive and meaningful relationship between distribution system and the success of tile industry.

The implementation of Kolmogorov-Smirnov has revealed that all data are normally distributed and we can use Pearson correlation to verify the relationship between the successes of tile industry with three mentioned variables. We also use the following three regression analyses,

Success of tile industry $=\beta_{0}+\beta_{1}$ marketing planning,

Success of tile industry $=\beta_{0}+\beta_{1}$ low cost production,

Success of tile industry $=\beta_{0}+\beta_{1}$ organizational capabilities .

Success of tile industry $=\beta_{0}+\beta_{1}$ technology,

Success of tile industry $=\beta_{0}+\beta_{1}$ distribution system.

The study uses ordinary least squares techniques to investigate the relationship between independent variable and dependent variables in Eqs. (1-5).

\section{The results}

In this section, we present details of our findings on testing different hypotheses of the survey based on Pearson correlation ratio as well as regression analysis.

\subsection{The first hypothesis: The relationship between the success of tile industry and marketing planning}

The first hypothesis of the survey investigates the relationship between the success of tile industry and making planning. Table 1 shows details of the implementation of Pearson correlation ratio.

\section{Table 1}

The results of Pearson correlation test

\begin{tabular}{cccc}
\hline Correlation ratio & Coefficient of determination & Adjusted ratio & Standard error \\
\hline .312 & .098 & .094 & 1.10104 \\
\hline
\end{tabular}

As we can observe from the results of Table 1, there is a positive and meaningful relationship between the success of tile industry and marketing planning. Table 2 shows details of regression analysis.

Table 2

The summary of regression analysis

\begin{tabular}{cccccc}
\hline & Non-standard $\beta$ & Standard error & Standard $\beta$ & $\mathrm{t}$ & Sig. \\
\hline (Constant) & 1.857 & .252 & & 7.356 & .000 \\
Marketing planning & .320 & .065 & .312 & 4.963 & .000 \\
\hline
\end{tabular}

The results of Table 2 also confirm that there is a positive and meaningful relationship between marketing planning and the success of tile industry. In other words, a good marketing planning could boost sales figures and help tile industry penetrate into market.

\subsection{The second hypothesis: The relationship between the success of tile industry and low cost} production

The second hypothesis of the survey studies the relationship between the success of tile industry and making planning. Table 3 presents details of the implementation of Pearson correlation ratio. 
Table 3

The results of Pearson correlation test for testing the second hypothesis

\begin{tabular}{cccc} 
Correlation ratio & Coefficient of determination & Adjusted ratio & Standard error \\
\hline .13 & .0169 & .389 & 0.90430 \\
\hline
\end{tabular}

As we can observe from the results of Table 3, there is not a strong and meaningful relationship between the success of tile industry and low cost production. Table 4 presents details of regression analysis.

Table 4

The summary of regression analysis between the success of tile industry and low cost production

\begin{tabular}{cccccc}
\hline & Non-standard $\beta$ & Standard error & Standard $\beta$ & $\mathrm{T}$ & Sig. \\
\hline (Constant) & 0.858 & .191 & & 0.490 & .121 \\
Low cost production & .651 & .051 & .13 & 1.104 & .130 \\
\hline
\end{tabular}

The results of Table 4 also confirm that there is not any meaningful relationship between marketing planning and the success of tile industry. It appears that the cost of production does not have much impact on the success of tile industry and the sector is suffering from other issues.

\subsection{The third hypothesis: The relationship between the success of tile industry and organizational capabilities}

The third hypothesis of the survey looks into the relationship between the success of tile industry and organizational capabilities. Table 5 presents details of the implementation of Pearson correlation ratio.

Table 5

The results of Pearson correlation test for testing the third hypothesis

\begin{tabular}{cccc}
\hline Correlation ratio & Coefficient of determination & Adjusted ratio & Standard error \\
\hline .635 & .403 & .400 & 0.89559 \\
\hline
\end{tabular}

As we can observe from the results of Table 5, there is a positive and meaningful relationship between the success of tile industry and organizational capabilities. Table 6 shows details of regression analysis.

Table 6

The summary of regression analysis for the relationship between organizational capabilities and the success of tile industry

\begin{tabular}{cccccc}
\hline & Non-standard $\beta$ & Standard error & Standard $\beta$ & $\mathrm{t}$ & Sig. \\
\hline (Constant) & 0.947 & .180 & & 5.257 & .000 \\
Organizational capabilities & .631 & .051 & .635 & 12.403 & .000 \\
\hline
\end{tabular}

The results of Table 6 also confirm state that there was a positive and meaningful relationship between organizational capabilities and the success of tile industry. In other words, good organizational capabilities could boost sales figures and help tile industry penetrate into market.

\subsection{The fourth hypothesis: The relationship between the success of tile industry and technology}

The fourth hypothesis of the survey investigates the relationship between the success of tile industry and technology. Table 7 shows details of the implementation of Pearson correlation ratio.

Table 7

The results of Pearson correlation test

\begin{tabular}{cccc}
\hline Correlation ratio & Coefficient of determination & Adjusted ratio & Standard error \\
\hline .437 & .191 & .187 & 1.04251 \\
\hline
\end{tabular}


As we can observe from the results of Table 7 , there is a positive and meaningful relationship between the success of tile industry and marketing planning. Table 8 shows details of regression analysis.

\section{Table 8}

The summary of regression analysis between the success of tile industry and technology

\begin{tabular}{rccccc}
\hline & Non-standard $\beta$ & Standard error & Standard $\beta$ & t & Sig. \\
\hline (Constant) & 1.317 & .247 & & 5.333 & .000 \\
Technology & .483 & .066 & .437 & 7.335 & .000 \\
\hline
\end{tabular}

The results of Table 8 also confirm that there is a positive and meaningful relationship between technology and the success of tile industry. In other words, the implementation of advanced technology could help tile industry for better management.

\subsection{The fifth hypothesis: The relationship between the success of tile industry and distribution system}

The fifth hypothesis of the survey investigates the relationship between the success of tile industry and distribution system. Table 9 shows details of the implementation of Pearson correlation ratio.

Table 9

The results of Pearson correlation test between the success of tile industry and distribution system

\begin{tabular}{cccc}
\hline Correlation ratio & Coefficient of determination & Adjusted ratio & Standard error \\
\hline .615 & .378 & .378 & 0.91384 \\
\hline
\end{tabular}

The results of Table 9 show that there is a positive and meaningful relationship between the success of tile industry and marketing planning. Table 10 shows details of regression analysis.

Table 10

The summary of regression analysis between the success of tile industry and distribution system

\begin{tabular}{cccccc}
\hline & Non-standard $\beta$ & Standard error & Standard $\beta$ & $\mathrm{t}$ & Sig. \\
\hline (Constant) & 0.910 & .192 & & 4.740 & .000 \\
Distributing system & .631 & .054 & .615 & 11.779 & .000 \\
\hline
\end{tabular}

The results of Table 10 also confirm that there was a positive and meaningful relationship between distributing system and the success of tile industry. In other words, a good distributing system could help tile industry succeed.

\section{Conclusion}

In this paper, we have presented a survey to study the relationship between five independent variables namely; marketing planning, low cost production and organizational capabilities with the success of tile industry. The implementation of Pearson correlation ratio as well as regression technique indicate that while there was no meaningful relationship between low cost production and the success of tile industry, there were positive and meaningful relationship between the success of tile industry with marketing planning, organizational capabilities, technology and distribution system.

\section{Acknowledgement}

The authors are grateful for constructive comments on earlier version of this paper, which has significantly contributed on the quality of the paper.

\section{References}

Borman, M., \& Janssen, M. (2013). Reconciling two approaches to critical success factors: The case of shared services in the public sector. International Journal of Information Management, 33(2), $390-400$. 
Chen, Y. (2012). The empirical analysis model on critical success factors for emergency management engineering information system. Systems Engineering Procedia, 5, 234-239.

Lu, X.H., Huang, L.H., Heng, M.S.H. (2006). Critical success factors of inter-organizational information systems-A case study of Cisco and Xiao Tong in China. Information \& Management, 43(3), 395-408.

Ram, J., Corkindale, D., \& Wu, M.L. (2013). Implementation critical success factors (CSFs) for ERP: Do they contribute to implementation success and post-implementation performance? International Journal of Production Economics, 144(1), 157-174.

Stankovic, D., Nikolic, V., Djordjevic, M., \& Cao, D.B. (2013). A survey study of critical success factors in agile software projects in former Yugoslavia IT companies. Journal of Systems and Software, 86(6), 1663-1678.

Sung, T.K. (2011). Dynamics of CSFs for business innovation: Normal vs. Crisis economic conditions. Technological Forecasting and Social Change, 78(8), 1310-1318.

Zou, W., Kumaraswamy, M., Chung, J., \& Wong, J. (2014). Identifying the critical success factors for relationship management in PPP projects. International Journal of Project Management, 32(2), 265-274. 